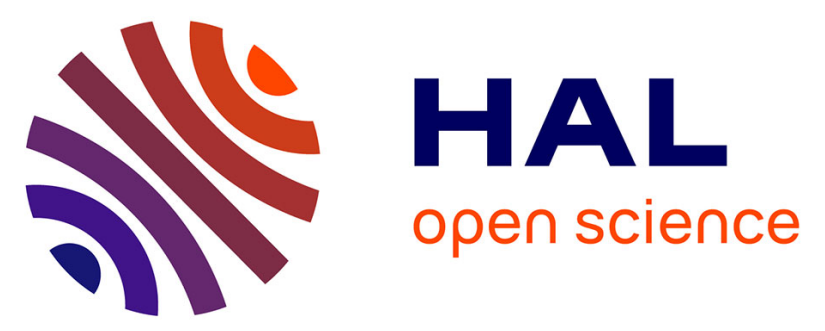

\title{
Phytoplankton composition and organic matter organization of mucous aggregates by means of light and cryo-scanning electron microscopy.
}

Nives Kovac, Patricija Mozetic, Jean Trichet, Christian Défarge

\section{- To cite this version:}

Nives Kovac, Patricija Mozetic, Jean Trichet, Christian Défarge. Phytoplankton composition and organic matter organization of mucous aggregates by means of light and cryo-scanning electron microscopy.. Marine Biology, 2005, 147, pp.1, 261-271. 10.1007/s00227-004-1531-3 . hal-00023437

\section{HAL Id: hal-00023437 \\ https://hal-insu.archives-ouvertes.fr/hal-00023437}

Submitted on 29 May 2006

HAL is a multi-disciplinary open access archive for the deposit and dissemination of scientific research documents, whether they are published or not. The documents may come from teaching and research institutions in France or abroad, or from public or private research centers.
L'archive ouverte pluridisciplinaire $\mathbf{H A L}$, est destinée au dépôt et à la diffusion de documents scientifiques de niveau recherche, publiés ou non, émanant des établissements d'enseignement et de recherche français ou étrangers, des laboratoires publics ou privés. 


\title{
Phytoplankton composition and organic matter organization of mucous aggregates by means of light and cryo-scanning electron microscopy
}

\author{
Nives Kova č ${ }^{1}$, Patricija Mozetič ${ }^{1}$, Jean Trichet ${ }^{2}$ and Christian Défarge ${ }^{2}$ \\ (1) Marine Biology Station, National Institute of Biology, Fornaze 41, 6330 Piran, \\ Slovenia \\ (2) Institut des Sciences de la Terre d'Orléans, UMR 6113 CNRS-Université \\ d'Orléans, BP 6759, 45067 Orléans cedex 2, France
}

\begin{abstract}
Two types of northern Adriatic mucous macroaggregates-surface and cloud-like-collected in June 2000 at the sea surface and at the depth of the pycnocline, respectively, were studied by light and cryo-scanning electron microscopy. The combination of both techniques permitted investigation of species/particle composition and particle-organic matrix associations of copious mucous aggregates. Both types of macroaggregates had, on average, heterogeneous composition with diatoms the dominant biotic component, differing by the prevailing species and stage of degradation. Some differences in the organization of the basic fibrillar organic network of macroaggregates were observed. Clouds were characterized by a tighter organization of the polysaccharidic fibrils within the walls of the organic network constituting the cloud. This organization was looser in the organic network within surface aggregates. Plankton remains and inorganic particles could lead to lower porosity and greater rigidity of these aggregates. The more complex organization of the organic matter and the intense growth of Cylindrotheca closterium within the clouds probably reflect a longer physical diagenesis of the polysaccharidic fibrils in comparison to surface aggregates.
\end{abstract}

\section{Introduction}

Sporadic developments of macroscopic mucous aggregates in the Adriatic Sea, usually during the late spring-summer, are now acknowledged and well documented. The historical sequence of such events has been reviewed by Fonda Umani et al. (1989) from the first documented appearance of aggregates in the eighteenth century and by Stachowitsch et al. (1990) during the second half of the twentieth century. But it was only after the late 1980s, when gelatinous amorphous macroaggregates appeared on a very large scale covering the entire area of the northern Adriatic, that systematic scientific effort has been focused on this phenomenon. Since then, aggregates have been studied with a spectrum of approaches to better understand the processes of macroaggregate formation and to provide possible explanations not only for scientists but for other groups economically dependent on exploitation of the sea (e.g., fisheries, tourism).

Northern Adriatic macroaggregates, which can be viewed, chemically, as macrogels (Alldredge et al. 1993), are built up of suspended organic and inorganic material. The organic fraction, considered to be generated by the gelling of phytoplankton exudates (Marchetti et al. 1989; Herndl 1992; Malej 1995; Myklestad 1995), behaves as a matrix for planktonic organisms and inorganic constituents. This general organization 
has been confirmed by chemical analyses (Ittekkot et al. 1982; Faganeli 1989; Posedel and Faganeli 1991; Hama and Handa 1992; Faganeli et al. 1995; Kovac et al. 1998) and microscopic observations (Fanuko et al. 1989; Stachowitsch et al. 1990; Degobbis et al. 1995; Baldi et al. 1997; P. Mozeti pointing to a pelagic origin and formation of macroaggregates in the water column.

In addition to a very heterogeneous biological component (phytoplankton, bacteria, zooplankton debris) embedded in an organic matrix, several inorganic components are present in the mucous (Stachowitsch et al. 1990; Pettine et al. 1995; Penna et al. $\underline{2000}$; Kova ce et al. 2002), as found in other macroscopic particles occurring worldwide and commonly identified as marine snow (Cowen and Holloway 1996; Heissenberger et al. 1996; Leppard et al. 1996). Inorganics can be considered as important aggregation agents due to their capability to adsorb (Arnarson and Keil 2000; Kaiser and Guggenberger 2000) or chemically link dissolved organic matter (Stevenson 1982), though their role in the formation of mucous aggregates is not completely clear. Kovac et al. (2002) indeed identified, in northern Adriatic macroaggregates, mineral particles consisting mostly of calcite, quartz, and clays. The interaction between organic matter, originating from phytoplankton exudates, and mineral particles probably enhances the agglomeration and stability of macroaggregates.

The mucoid organic matrix of northern Adriatic macroaggregates is chemically composed of four major structural constituents. Kovac et al. (2002) identified polysaccharides, an aliphatic component, organic molecules bearing functional groups such as esters and amides, and organosilicon compounds. A general characteristic of polysaccharides is to form a network, often observed in particles of marine snow (Decho 1990; Heissenberger et al. 1996; Leppard et al. 1996) and lately in northern Adriatic mucous (Giani 2002) with the use of electron microscopy.

Mucous macroaggregates usually become visible when they appear in the water column or at the sea surface in the form of different types and/or stages of floating bodies (Stachowitsch et al. 1990). The June 2000 event provided a unique opportunity to study the different types of macroaggregates due to their stability and persistence in the seawater. In the present article, phytoplankton composition and the morphological features of macroaggregates are reported through observations by means of light and cryo-scanning electron microscopy (cryo-SEM). While light microscopy enabled identification of organisms and particles, cryo-SEM proved to be essential for determining ultrastructure of the organic amorphous matrix and its principal component, polysaccharidic fibrils as thin as about $20 \mathrm{~nm}$.

\section{Materials and methods Study site and sampling}

Mucous macroaggregates were collected in June 2000 in the water column and at the sea surface in the southeastern part of the Gulf of Trieste (northern Adriatic Sea, Slovenia) with a minimal amount of surrounding water. Water-column aggregates were in the form of cloud-like bodies exceeding a few meters in size (Fig. 1) and were collected by SCUBA divers at depths of $12-15 \mathrm{~m}$. Those floating at the sea surface, always brought on shore around noon due to onshore winds (Fig. 2), were sampled 
by hand in front of the Piran Marine Biology Station (MBS) using polyethylene bottles. Because of the gelatinous nature of macroaggregates it was possible to sample them with a minimal amount of surrounding water.

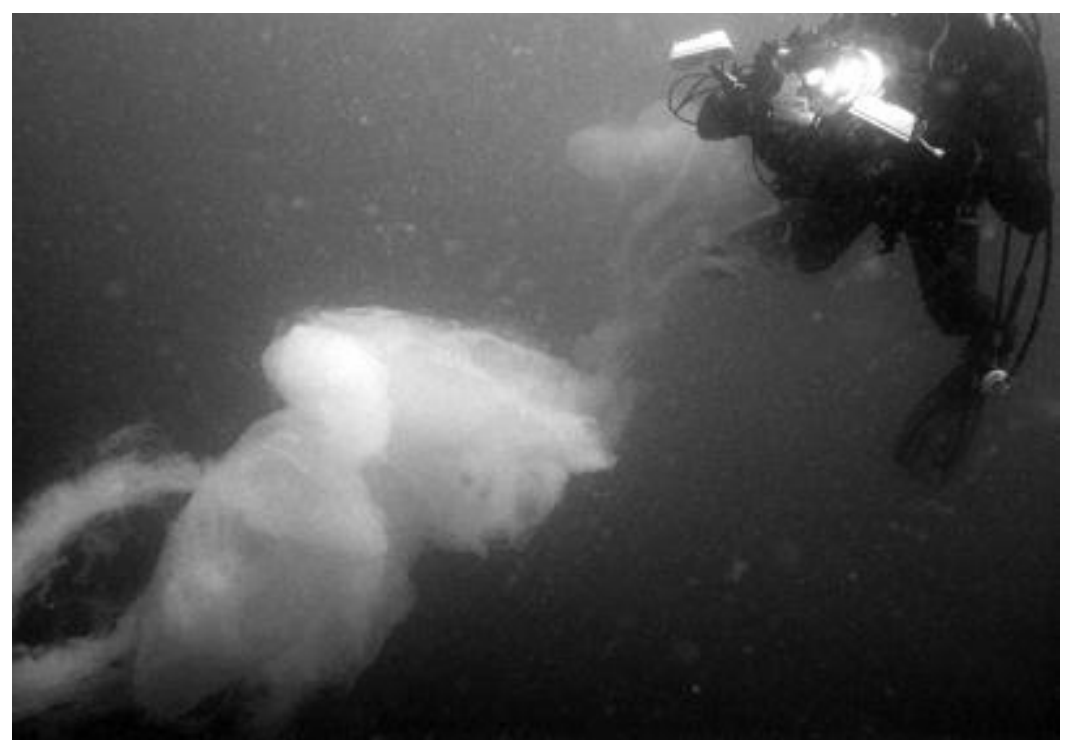

Fig. 1 Water-column aggregates in the form of clouds (photo: T. Makovec)

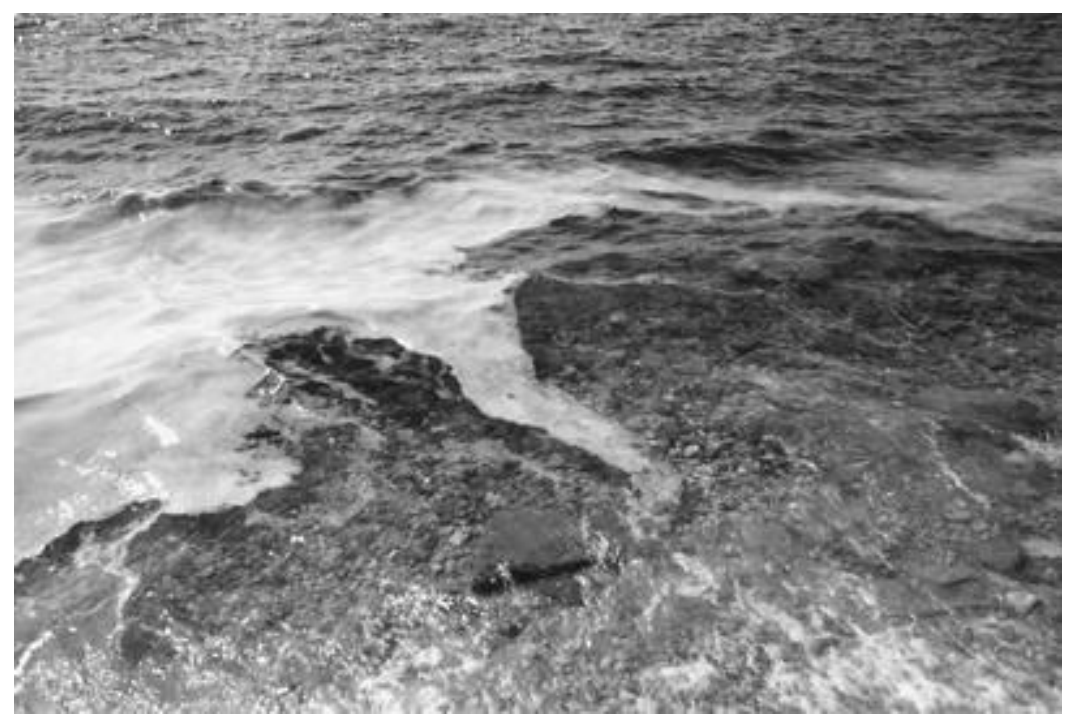

Fig. 2 Surface macroaggregates accumulating on the shore in front of the Piran Marine Biology Station, Adriatic Sea (photo: V. Bernetic)

\section{Light microscopy}

Samples consisting of approximately $100 \mathrm{ml}$ of gelatinous hydrated material with a minimal amount of surrounding water were fixed with $2 \%$ formalin (final concentration). A small piece of gel was placed on a microscope slide and three replicates (samples 1, 2, 3) of each macroaggregate type were examined. Light microscopic observations were made at $200 \times$ and $400 \times$ magnification using transmittal and epifluorescent microscopy to check for live, autotrophic organisms. Using this purely qualitative approach, estimates of the abundance of organisms and particles were made and assigned to "classes of abundance." Phytoplankton status 
was also noted, for example, live cells versus different stages of degradation (details are given in Table $\underline{1}$ ).

\section{Organisms and particles}

\begin{tabular}{|l|l|l|l|l|l|l|l|}
\hline \multicolumn{2}{|l|}{ Sample 1 } & \multicolumn{2}{l|}{ Sample 2 } & \multicolumn{2}{l|}{ Sample 3 } & IW & SSW \\
\hline CA & Status & CA & Status & CA & Status & $\begin{array}{l}\text { Cells I' } \\
1\end{array}$ & $\begin{array}{l}\text { Cells I' } \\
1\end{array}$ \\
\hline
\end{tabular}

\section{Diatoms}

\begin{tabular}{|c|c|c|c|c|c|c|c|c|}
\hline Amphiprora sp. & - & & - & & - & & & $1.1 \times 10^{4}$ \\
\hline Bacteriastrum sp. & - & & - & & - & & & $3.7 \times 10^{3}$ \\
\hline Cerataulina pelagica & - & & - & & + & $D$ & $5.0 \times 10^{3}$ & $8.7 \times 10^{3}$ \\
\hline Chaetoceros anastomosans & - & & - & & - & & & $8.7 \times 10^{3}$ \\
\hline Chaetoceros sp. & - & & + & $\mathrm{D}, \mathrm{Fr}$ & + & $\mathrm{D}, \mathrm{Fr}$ & & $3.3 \times 10^{5}$ \\
\hline Cyclotella sp. & +++ & $\mathrm{L}$ & +++ & $\mathrm{L}, \mathrm{Fr}$ & ++ & $\mathrm{L}$ & $1.3 \times 10^{6}$ & $8.7 \times 10^{3}$ \\
\hline Cylindrotheca closterium & +++ & L & +++ & $L(d)$ & +++ & $\mathrm{L}$ & $5.9 \times 10^{5}$ & $9.1 \times 10^{4}$ \\
\hline Dactyliosolen fragilissimus & - & & - & & - & & $5.0 \times 10^{3}$ & $2.5 \times 10^{3}$ \\
\hline Hemiaulus hauckii & - & & + & $\mathrm{D}, \mathrm{Fr}$ & + & $\mathrm{D}$ & & $1.2 \times 10^{3}$ \\
\hline Licmophora sp. & + & $\mathrm{D}, \mathrm{Fr}$ & + & L & - & & $1.5 \times 10^{4}$ & \\
\hline Pleurosigma sp. & - & & - & & + & L, D & & \\
\hline Proboscia alata & - & & + & $\mathrm{Fr}$ & - & & & $6.2 \times 10^{3}$ \\
\hline Pseudo-nitzschia pseudodel. & +++ & L & +++ & $D, L$ & ++++ & $L(d)$ & $5.2 \times 10^{5}$ & $7.5 \times 10^{3}$ \\
\hline Rhizosolenia sp. & + & $\operatorname{Fr}(\mathrm{l})$ & - & & - & & & \\
\hline Thalassionema nitzschioides & - & & + & $L, D$ & - & & & \\
\hline Unidentified benthic diatoms & - & & ++ & $L, D$ & - & & $2.5 \times 10^{4}$ & $6.2 \times 10^{3}$ \\
\hline \multicolumn{9}{|l|}{ Dinoflagellates } \\
\hline Alexandrium sp. & - & & + & Th & - & & & \\
\hline Ceratium candelabrum & - & & - & & + & Th & & \\
\hline Ceratium furca & - & & + & Th & + & Th & & \\
\hline Ceratium fusus & - & & + & Th & + & Th & & \\
\hline Dinophysis sacculus & - & & - & & + & Th & & \\
\hline Diplopsalis lenticula group & + & Th & + & Th & + & Enc & & \\
\hline Gonyaulax fragilis & - & & - & & - & & & $7.5 \times 10^{3}$ \\
\hline Gonyaulax scrippsae & - & & + & Th, C & - & & & \\
\hline Gymnodinium sp. & + & $\mathrm{L}$ & - & & + & $L$ & $5.0 \times 10^{3}$ & $3.7 \times 10^{3}$ \\
\hline \multirow{2}{*}{ Heterocapsa sp. } & ++ & Th & ++ & L & + & L & $1.8 \times 10^{5}$ & \\
\hline & 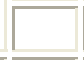 & & ++ & Th & ++ & Th & & \\
\hline Lingulodinium polyedrum & - & & + & Th & - & & & \\
\hline Mesoporos perforatus & - & & - & & + & Th & & \\
\hline Prorocentrum aporum & - & & + & Th & - & & & \\
\hline Prorocentrum balticum & - & & + & Th & - & & $5.0 \times 10^{3}$ & \\
\hline \multirow{2}{*}{ Prorocentrum gracile } & + & Th & + & L & ++ & Th & $5.0 \times 10^{3}$ & $1.2 \times 10^{3}$ \\
\hline & - & & +++ & Th & & & & \\
\hline Prorocentrum lima & - & & - & & - & & $5.0 \times 10^{3}$ & \\
\hline \multirow{2}{*}{ Prorocentrum micans } & - & & + & $\mathrm{L}$ & + & $\mathrm{L}$ & & \\
\hline & 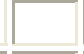 & & + & Th & + & Th & & \\
\hline \multirow{2}{*}{ Prorocentrum minimum } & + & Th & ++ & Th & ++ & $\mathrm{L}$ & & \\
\hline & & & & & +++ & Th & & \\
\hline \multirow{2}{*}{ Prorocentrum triestinum } & ++ & Th & ++ & $\mathrm{L}$ & + & $\mathrm{L}$ & $5.0 \times 10^{3}$ & \\
\hline & & & +++ & Th & ++ & Th & & \\
\hline
\end{tabular}




\begin{tabular}{|c|c|c|c|c|c|c|c|c|}
\hline \multirow{2}{*}{ Organisms and particles } & \multicolumn{2}{|c|}{ Sample 1} & \multicolumn{2}{|c|}{ Sample 2} & \multicolumn{2}{|c|}{ Sample 3} & \multirow{2}{*}{\begin{tabular}{|l|} 
IW \\
Cells I'
\end{tabular}} & \multirow{2}{*}{ 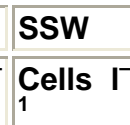 } \\
\hline & CA & Status & CA & Status & CA & Status & & \\
\hline Protoperidinium sp. & + & Th & + & Th & - & & & \\
\hline Scrippsiella trochoidea & - & & + & Th & + & C & & \\
\hline Unidentified naked dinofalgellates & - & & - & & +++ & Enc & $2.5 \times 10^{4}$ & $1.4 \times 10^{4}$ \\
\hline \multicolumn{9}{|l|}{ Coccolithophorids } \\
\hline Calyptrosphaera oblonga & + & $\begin{array}{l}\mathrm{D} / \mathrm{B} \\
\operatorname{cocc}\end{array}$ & + & L & + & $L, \operatorname{cocc}$ & & \\
\hline Emiliania huxleyi & - & & - & & + & $\mathrm{L}$ & $5.0 \times 10^{3}$ & \\
\hline Rhabdosphaera stylifer & + & $\begin{array}{l}\mathrm{D} / \mathrm{B} \\
\mathrm{cocc}\end{array}$ & + & $\begin{array}{l}\mathrm{B}(\mathrm{l}) \\
\operatorname{cocc}\end{array}$ & + & $\begin{array}{l}\mathrm{B}(\mathrm{l}) \\
\operatorname{cocc}\end{array}$ & & \\
\hline Syracosphaera pulchra & - & & + & L, cocc & + & $\operatorname{cocc}$ & & $2.5 \times 10^{3}$ \\
\hline Unidentified coccolithoph. & + & L & ++ & L, D & + & L & $4.0 \times 10^{4}$ & $8.7 \times 10^{3}$ \\
\hline Microflagellates & ++ & L & +++ & L & +++ & L & $1.8 \times 10^{6}$ & $2.5 \times 10^{5}$ \\
\hline Euglenophytes & - & & + & L, D & + & $L$ & $1.3 \times 10^{5}$ & \\
\hline Prasinophytes & - & & - & & - & & $7.0 \times 10^{4}$ & \\
\hline Raphidophytes & - & & - & & + & $L$ & $5.0 \times 10^{4}$ & \\
\hline \multicolumn{9}{|l|}{ Other } \\
\hline Bacteria_filamentous & - & & - & & + & & & \\
\hline $\begin{array}{l}\text { Zooplankton remains (broken cuticles, } \\
\text { antennae of Penilia) }\end{array}$ & + & & - & & + & & & \\
\hline Broken horns of Ceratium spp. & - & & ++ & & + & & & \\
\hline Fecal pellets & - & & - & & - & & & \\
\hline Detritus, mineral particles & - & & - & & + & & & \\
\hline
\end{tabular}

Table 1 List of organisms and particles found in three different surface macroaggregates, collected in front of Marine Biology Station, Piran (June 2000, Adriatic Sea). They are classified in five classes of abundance (CAs): $(-)$ absent, (+) present, $(++)$ abundant, (+++) very abundant, (++++) dominating species. The following categories describe the status of phytoplankton species: live $(L)$ and dead $(D)$ cells, empty diatom frustules $(F r)$ and dinoflagellate thecas $(T h)$, dead and/or broken coccolithophorids $(D / B)$, loose coccoliths (cocc), encysting dinoflagellates $(E n c)$, dinoflagellate cysts $(C)$, senescent cells $[L(d)]$, mainly empty frustules but also live diatoms $[\operatorname{Fr}(I)]$, mainly broken but also live coccolithophorids $[B(I)]$. Densities of phytoplankton cells (cells per liter) in samples of the interstitial water (IW) and aggregate-free surrounding seawater (SSW) are also shown

Microscopic composition of gelatinous aggregates was difficult to determine due to stickiness and heterogeneity of the material: overlaying of particles in the multilayered gel mounted on the slide. Quantification by commonly used microscopic methods was therefore not possible. An approximate phytoplankton density was determined by enumerating cells in the water drawn off the gelatinous hydrated material (i.e. interstitial water) after $24 \mathrm{~h}$ in a glass cylinder. Twenty-five milliliters of the interstitial water was collected below the gelatinous body and cells counted under an inverted microscope using the Utermöhl method (1958). Additionally, a 50-ml subsample of the aggregate-free surrounding seawater was examined to compare its phytoplankton composition with the interstitial water and to estimate the density enrichment factor. Seawater was collected in the subsurface layer of the 16-m deepwater column near the MBS during the same period of the collection of surface macroaggregates. 


\section{The cryo-SEM technique}

The same samples-surface aggregates and clouds-were processed for cryo-SEM. This technique (Défarge 1997) involves preservative freeze-drying of the sample before observation under the electron beam. The method consists of plunging the sample (less than $1 \mathrm{~mm}^{3}$ ) into a very cool liquid (slush $\mathrm{N}_{2}$ near to $-210^{\circ} \mathrm{C}$ ). Freezing is so rapid that ice crystals cannot displace any volume and consequently do not alter the finest structures in the sample at the SEM observation scale. After breaking the sample to obtain a sharp and clean surface, the sublimation of "solid water" contained in a thin surface layer, by heating to $-90^{\circ} \mathrm{C}$, reveals the finest details of the sample. Constituents are observed in the refrigerated chamber of the scanning microscope at approximately $-150^{\circ} \mathrm{C}$. The field emission technique, providing an electron beam with high density, coherence, and accuracy, enables a high resolution without metallizing the sample and under a much lower voltage (1 kV) useful for observation of organic constituents.

The chemical microprobe (Oxford, Link Isis, Li/Si detector) uses the emission of $X$ rays by the atoms of the sample, under the electron beam excitation. The apparatus is an energy/dispersive spectrometer (EDS).

\section{Results}

\section{Light microscopy observations}

Results of microscopic observations are presented separately for two types of macroaggregates (sensu Stachowitsch et al. 1990), which differ by their appearance/consistency and position in the water column. The extremely heterogeneous nature of macroaggregates, regarding organisms, particles, and unidentified structures, was observed (Fig. $\underline{3}$ ), yielding a highly variable composition characteristic of different samples of the same type of aggregates (Tables $\underline{1}, \underline{2})$.

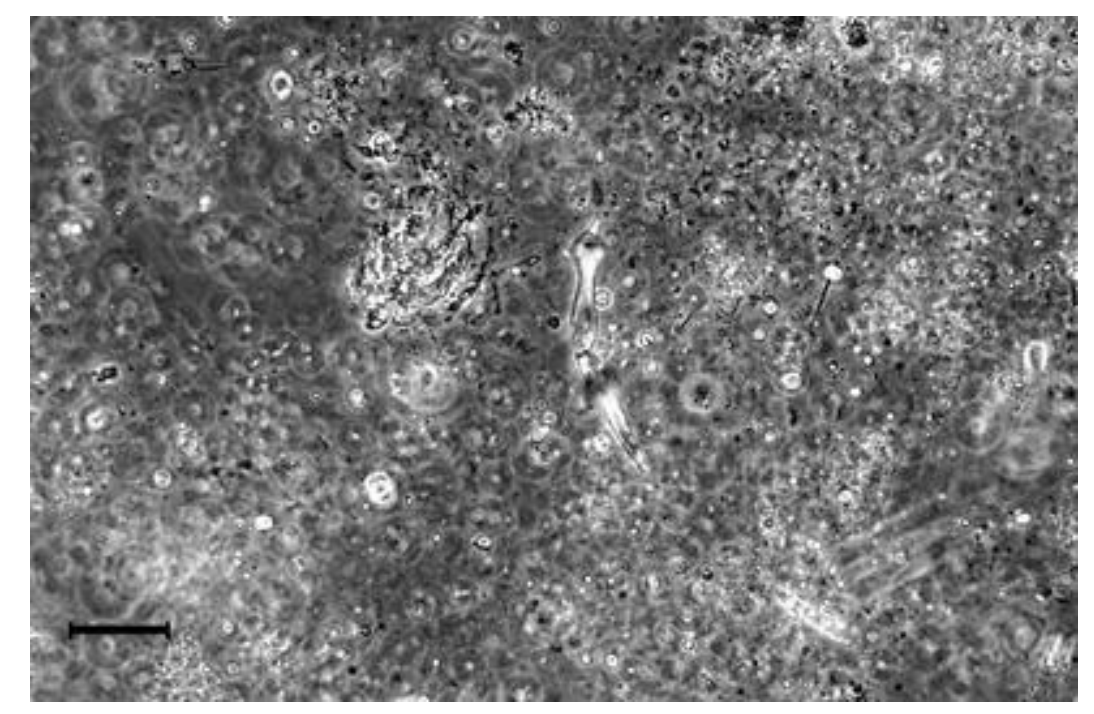

Fig. 3 Heterogeneous structure of surface macroaggregates. Among a variety of organisms and particles, some amoeboid structures can be observed (scale bar $60 \mu \mathrm{m}$ ) 
Material constituting surface macroaggregates was very dense and gelatinous, whiteyellow to dark brown with many gas bubbles (Figs. $\underline{3}$, 4 ). Practically impossible to pipette, a small piece of spongy mucous was examined showing a variety of organisms and particles in surface macroaggregates collected in front of MBS (Table 1). A high species diversity of dinoflagellates was noted in most samples, especially of the genus Prorocentrum; empty thecae (Th) prevailed over live cells (L) (Table 1). Live specimens were found associated with species $P$. triestinum, $P$. minimum, $P$. micans, $P$. gracile, Heterocapsa sp., and a naked Gymnodinium-like dinoflagellate. The most frequent species were Heterocapsa $\mathrm{sp}$. and $P$. triestinum. Some dinoflagellates formed cysts $(C)$ or were going through the process of encystment (Enc).

\begin{tabular}{|c|c|c|c|c|c|c|}
\hline \multirow{2}{*}{ Organisms and particles } & \multicolumn{2}{|c|}{ Sample 1} & \multicolumn{2}{|c|}{ Sample 2} & \multicolumn{2}{|c|}{ Sample 3} \\
\hline & CA & Status & CA & Status & CA & Status \\
\hline \multicolumn{7}{|l|}{ Diatoms } \\
\hline Amphiprora sp. & + & L & - & & + & L \\
\hline Asteromphalus heptactis & - & & - & & + & $\mathrm{D}$ \\
\hline Cerataulina pelagica & + & $\mathrm{Fr}$ & ++ & $\mathrm{Fr}$ & + & $\mathrm{D}$ \\
\hline Chaetoceros sp. & ++ & Fr, $\operatorname{Fr}(\mathrm{I})$ & ++ & Fr, $\operatorname{Fr}(\mathrm{I})$ & ++ & $\begin{array}{l}\text { Fr, } \\
\text { spores }\end{array}$ \\
\hline Cyclotella sp. & +++ & $\operatorname{Fr}(\mathrm{l})$ & ++ & $\operatorname{Fr}(\mathrm{l})$ & ++ & $\operatorname{Fr}(\mathrm{l})$ \\
\hline Cylindrotheca closterium & +++ & $\mathrm{L}$ & +++ & L & ++++ & L \\
\hline Guinardia flaccida & + & $\mathrm{Fr}$ & - & & - & \\
\hline Hemiaulus hauckii & + & $D$ & + & $D$ & - & \\
\hline Pleurosigma sp. & - & & + & L, D & + & L, D \\
\hline Proboscia alata & + & $\mathrm{Fr}$ & - & & - & \\
\hline Pseudo-nitzschia pseudodel. & ++++ & $\mathrm{D}, \operatorname{Fr}(\mathrm{I})$ & +++ & L, D & ++ & Fr, D \\
\hline Rhizosolenia sp. & + & $\mathrm{Fr}$ & - & & - & \\
\hline Thalassionema nitzschioides & - & & - & & + & $\mathrm{D}$ \\
\hline Unidentified benthic diatoms & - & & + & $\mathrm{L}$ & - & \\
\hline \multicolumn{7}{|l|}{ Dinoflagellates } \\
\hline Alexandrium sp. & + & Th & + & Th & - & \\
\hline Dinophysis sacculus & + & Th & + & Th & - & \\
\hline Diplopsalis lenticula group & ++ & Th & + & Th & - & \\
\hline Gonyaulax sp. & + & Th & + & Th & - & \\
\hline Gonyaulax scrippsae & + & Cysts & - & & - & \\
\hline \multirow{2}{*}{ Heterocapsa sp. } & ++ & Th & ++ & L & ++ & Th \\
\hline & 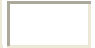 & & +++ & PTk. & & \\
\hline Mesoporos perforatus & + & Th & + & Th & & \\
\hline Oxytoxum adriaticum & - & & - & & + & Th \\
\hline Oxytoxum tesselatum & - & & + & Th & - & \\
\hline Prorocentrum aporum & - & & - & & + & Th \\
\hline \multirow{2}{*}{ Prorocentrum gracile } & +++ & Th & + & $\mathrm{L}$ & ++ & Th \\
\hline & & & + & Th & & \\
\hline Prorocentrum micans & + & Th & - & & - & \\
\hline \multirow{2}{*}{ Prorocentrum minimum } & + & L & + & Th & +++ & Th \\
\hline & +++ & Th & & & & \\
\hline Prorocentrum triestinum & ++ & Th & ++++ & Th & ++ & Th \\
\hline
\end{tabular}




\begin{tabular}{|c|c|c|c|c|c|c|}
\hline \multirow{2}{*}{ Organisms and particles } & \multicolumn{2}{|c|}{ Sample 1} & \multicolumn{2}{|c|}{ Sample 2} & \multicolumn{2}{|c|}{ Sample 3} \\
\hline & CA & Status & CA & Status & CA & Status \\
\hline Protoperidinium diabolus & + & Th & - & & + & Th \\
\hline Protoperidinium sp. & + & Th & - & & + & Th \\
\hline \multirow{2}{*}{ Scrippsiella trochoidea } & + & Th, C & - & & + & Th \\
\hline & & & & & + & C \\
\hline \multicolumn{7}{|l|}{ Coccolithophorids } \\
\hline Calyptrosphaera oblonga & ++ & $\begin{array}{l}\mathrm{D} / \mathrm{B} \\
\mathrm{cocc}\end{array}$ & ++ & $\mathrm{D} / \mathrm{B}, \operatorname{cocc}$ & +++ & $L, \operatorname{cocc}$ \\
\hline Emiliania huxleyi & - & & - & & + & $\mathrm{L}$ \\
\hline Rhabdosphaera stylifer & + & $\begin{array}{l}\mathrm{D} / \mathrm{B} \\
\mathrm{cocc}\end{array}$ & ++ & $\begin{array}{ll}\text { L, } & B, \\
\operatorname{cocc} & \end{array}$ & + & $\mathrm{D} / \mathrm{B}, \mathrm{cocc}$ \\
\hline Syracosphaera pulchra & ++ & L & + & $L$ & + & $\mathrm{L}, \operatorname{cocc}$ \\
\hline Unidentified coccolithoph. & ++ & $L, D$ & + & $L$ & - & \\
\hline Microflagellates & +++ & L & +++ & $\mathrm{L}$ & +++ & L \\
\hline Euglenophytes & - & & ++ & $L$ & + & L \\
\hline Prasinophytes & - & & - & & + & $\mathrm{L}$ \\
\hline \multicolumn{7}{|l|}{ Other } \\
\hline Bacteria-spirals, rods & + & & - & & + & \\
\hline Tintinnids & +++ & & - & & ++ & \\
\hline \begin{tabular}{|l} 
Zooplankton remains (broken cuticles, antennae of \\
Penilia)
\end{tabular} & +++ & & + & & + & \\
\hline Dinoflagellates ${ }^{3}$ cysts & + & & ++ & & - & \\
\hline Broken horns of Ceratium spp. & + & & - & & - & \\
\hline Fecal pellets & ++ & & + & & + & \\
\hline Detritus, mineral particles & - & & - & & + & \\
\hline
\end{tabular}

Table 2 List of organisms and particles found in three different cloud-like aggregates, collected in the water column at 12-15 m depth in an offshore station in the Gulf of Trieste (June 2000, Adriatic Sea). For abbreviations and legend see Table $\underline{1}$

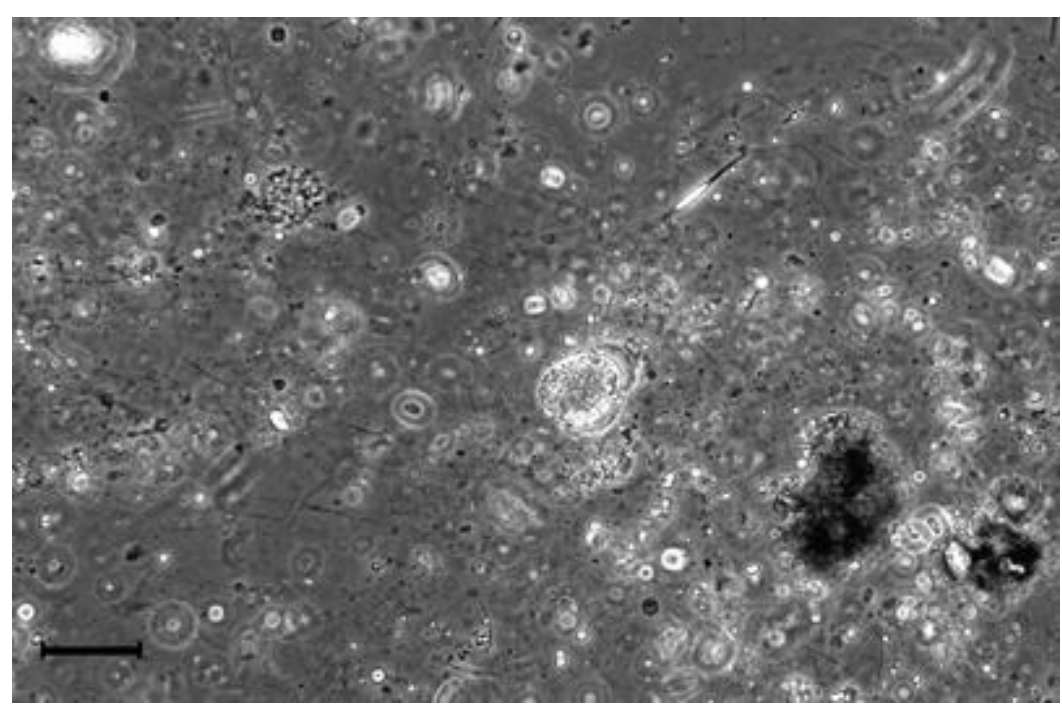

Fig. 4 Surface macroaggregates. Some naked Gymnodinium-like dinoflagellate can be observed (scale bar $60 \mu \mathrm{m})$ 
In contrast to dinoflagellates, live (L) prevailed over dead (D) diatoms and empty frustules ( $\mathrm{Fr}$ ). In surface samples the prevailing diatom species were Cylindrotheca closterium, Cyclotella sp., and Pseudo-nitzschia pseudodelicatissima. The first two were found as live cells; the other was senescent $[L(d)]$ and was the predominant species in one of the samples (sample 1).

Our descriptive quantification of mucous agreed with cell counts in the interstitial water (Table 1). Diatoms accounted for $51 \%$ of total cell numbers $\left(4.8 \times 10^{6}\right.$ cells $\left.\left.\right|^{-1}\right)$ and the most abundant diatoms belonged to the same three species as in the aggregates (Fig. ). Some live benthic diatoms were also recorded, indicating the resuspension of sediment and interaction with mucous material in the shallow water column. Other diatom species, typical for the summer pelagic community, were less frequent $(+)$ in macroaggregates and present mainly as empty frustules (Table $\underline{1}$ ). In addition to diatoms, other live and very abundant $(+++)$ phytoplankters were small (approximately $10 \mu \mathrm{m}$ ), unidentified flagellates referred to as microflagellates. Among them, euglenophytes and raphidophytes were identified, the former being very abundant in the interstitial water $\left(1.3 \times 10^{5}\right.$ cells $~^{-1}$; Fig. $\left.\underline{5}\right)$. Coccolithophorids were mainly dead and broken (D/B), so quantities of their skeletal calcite elements, coccoliths (cocc), were dispersed in the organic network. Some live species (Calyptrosphaera oblonga, Emiliania huxleyi, and Syracosphaera pulchra) were found, though in very low abundance (+). In comparison to the interstitial water, seawater without visible macroaggregates (i.e. the surrounding water) had much lower phytoplankton abundance $\left(7.7 \times 10^{5}\right.$ cells $^{-1}$; Table 1$)$. Diatoms prevailed even more than in the interstitial water (63\% of the total cell numbers). They attained higher species diversity and Chaetoceros $\mathrm{sp}$. was the predominant species $\left(3.3 \times 10^{5}\right.$ cells $\mathrm{I}^{-1}$ or $70 \%$ of total diatom density). The abundance and relative portions of Cyclotella sp., C. closterium, and P. pseudodelicatissima were much lower than in the interstitial water. The composition of dinoflagellates and coccolithophorids was also different.

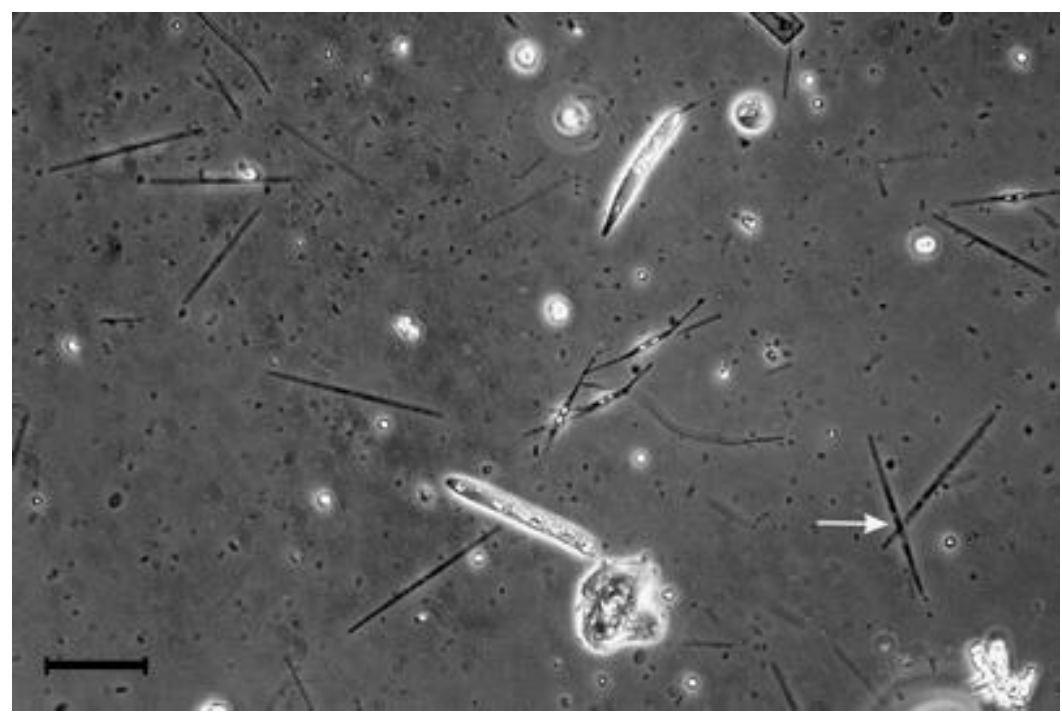

Fig. 5 Diatom-rich interstitial water sample of surface macroaggregates. Some euglenophytes, unidentified microflagellates, and cells of Pseudo-nitzschia pseudodelicatissima (arrow) can be observed (scale bar $30 \mu \mathrm{m})$ 
A variety of other organisms and/or parts of them (bacteria, zooplankton and related remains such as crustacean cuticles and antennae, faecal pellets), detritus, and mineral particles were also found enclosed in the matrix (Fig. $\underline{6}$ ), indicating intense scavenging processes.

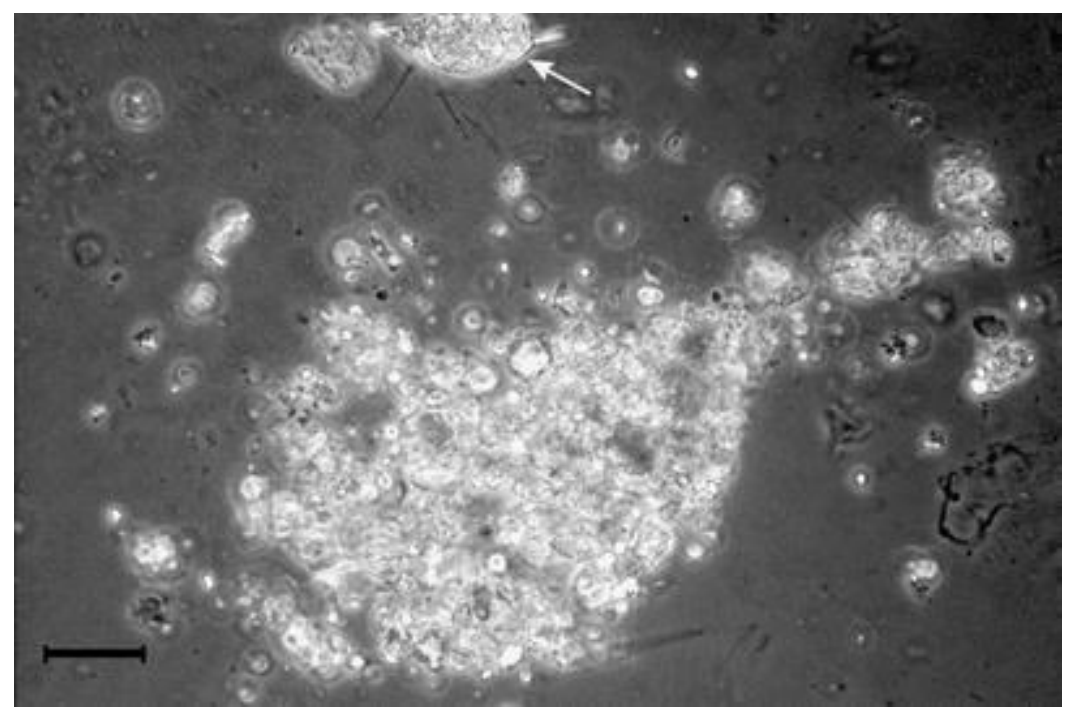

Fig. 6 Part of the surface aggregate with many mineral particles embedded; live Prorocentrum gracile (arrow) at the top of the micrograph (scale bar $30 \mu \mathrm{m}$ )

Clouds were collected in the water column at a depth of 12-15 $\mathrm{m}$. At first glance, the most evident visible differences between these clouds and surface bodies were in consistency, stability, and colour. While the surface aggregates were very compact and gelatinous, the cloud-like aggregates were more rigid and therefore easier to sample (Figs. $\underline{7}, \underline{8}$ ).

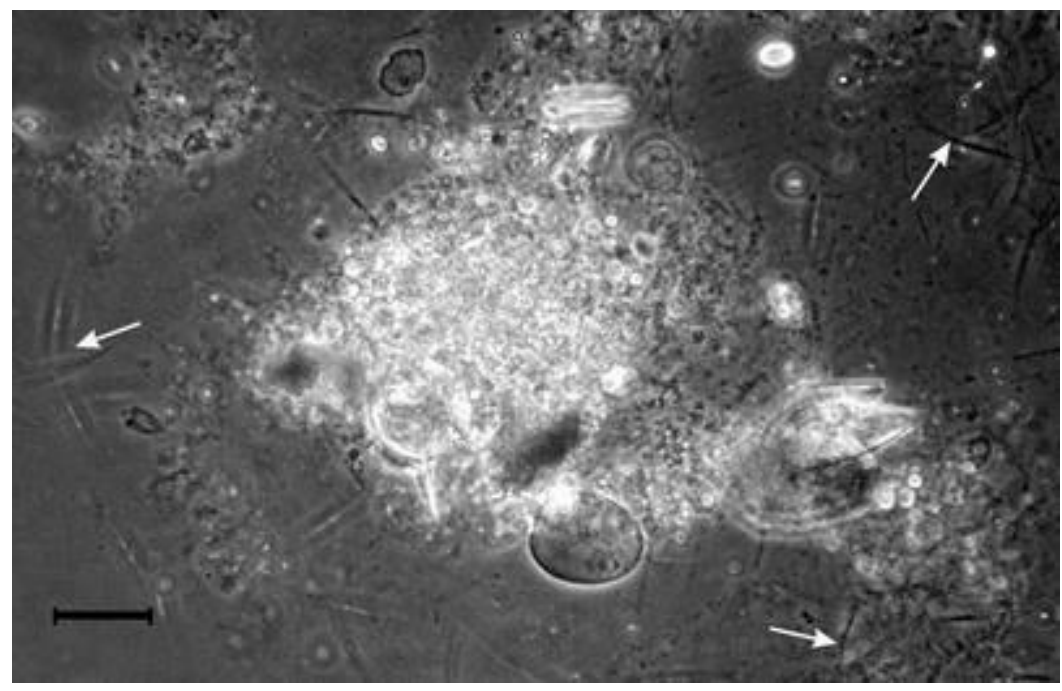

Fig. 7 Empty dinoflagellate thecae, detritus, mineral particles, and the prevailing live species, the diatom Cylindrotheca closterium (arrow), characterize the cloud-like aggregates (scale bar $30 \mu \mathrm{m}$ ) 


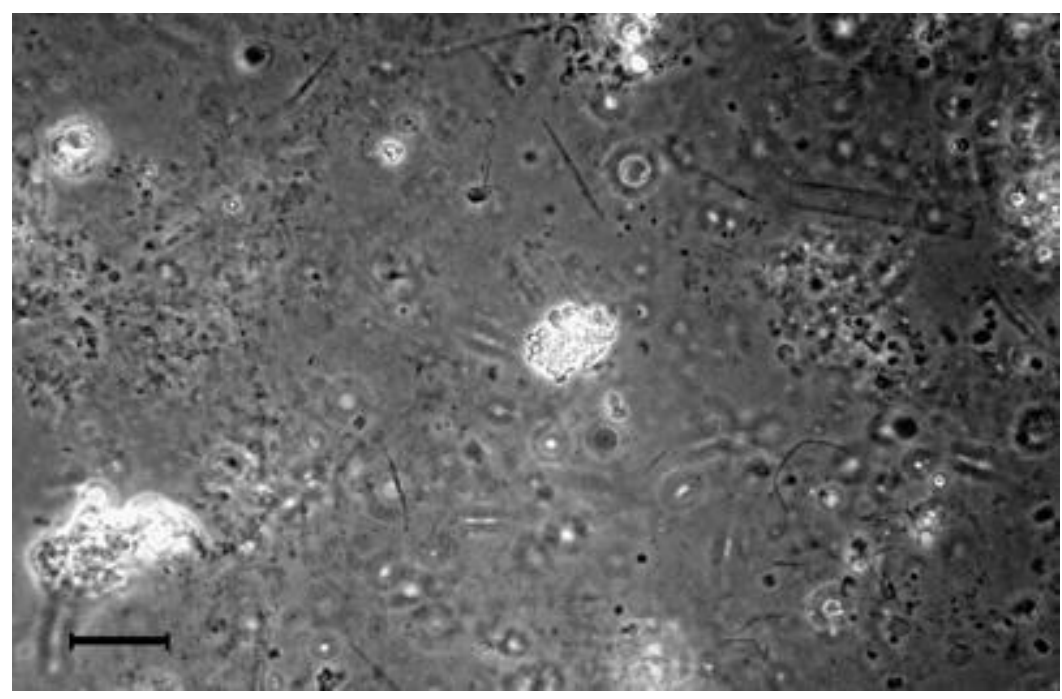

Fig. 8 Structure of clouds. A more decayed structure as compared with that of surface macroaggregates can be seen (scale bar $30 \mu \mathrm{m}$ )

Under the microscope, the filamentous structure of the clouds was especially evident. In all three observed samples (Table 2), there were almost no live dinoflagellates but large quantities of empty thecae found in the organic matrix. Some live specimens (L) of Heterocapsa sp., Prorocentrum gracile, and $P$. minimum were sporadically observed. Empty thecae (Th) of $P$. triestinum and Heterocapsa sp. were the most abundant $(++++$ and +++$)$ of all dinoflagellates, although these two species were found alive in the surface macroaggregates. Moreover, dinoflagellate species diversity was lower in the clouds: 17 species in the clouds compared to 20 in the surface macroaggregates. The number of identified diatoms was almost the same in both macroaggregate types (12 and 13, respectively). The dominant diatom species in the clouds were the same as in the surface samples, Cylindrotheca closterium, Cyclotella sp., and Pseudo-nitzschia pseudodelicatissima. However, $P$. pseudodelicatissima and Cyclotella sp. were mostly dead and empty (D, Fr) or decaying $[\mathrm{Fr}(\mathrm{I})]$, while $\mathrm{C}$. closterium was predominant $(++++)$ and almost the only live diatom (see Fig. 8). Another difference between the two types was the modest abundance (++) of dead and empty Chaetoceros spp. in the clouds, with many forming spores, which was not the case in surface macroaggregates.

Coccolithophorids, such as Emiliania huxleyi, Syracosphaera pulchra, and Calyptrosphaera oblonga, were more abundant and alive in the clouds compared to the surface macroaggregates. C. oblonga was the most abundant species (+++) of all coccolithophorids. Microflagellates were abundant and alive as well and, among them, some green algae (euglenophytes and prasinophytes) were identified. Essentially the same non-phytoplankton organisms, their remains and resting stages, detritus and mineral particles, were found in the clouds as well as in the surface macroaggregates. Tintinnids were found to be quite abundant in the clouds whereas they were not found in the surface samples.

Ultrastructure of macroaggregates

Observations under the cryo-SEM revealed the ultrastructure of the surface aggregates (Fig. $\underline{9}$ ) and clouds (Fig. 10). At low magnification (1,500×, Fig. $\underline{9}$, top), 
surface aggregates looked simply organized, with pores (size of ca. 4-13 $\mu \mathrm{m}$ ) surrounded by an aggregated organic matter. At a higher magnification $(9,000 \times$, Fig. $\underline{9}$, bottom), the organic matter revealed to be organized in pores (size ca. $1.5 \mu \mathrm{m}$ ) surrounded by thin organic membranes and threads.

The ultrastructure of the clouds suggests a firmer, less gelatinous, and less sticky consistency than that of the surface macroaggregates. At low magnification (350x, Fig. 10a), a fundamentally porous (size of ca. $4-30 \mu \mathrm{m}$ ) structure was noted, somewhat similar to that of pores in the surface aggregates (Fig. $\underline{9}$, top). The structure of the organic matter surrounding the pores, observed at a higher magnification (9,000x, Fig. 10b), appeared essentially fibrillar and resulted from the coalescence of elementary fibrils. The geometric organization of the rearranged fibrils resulted in the delineation of a second type of pore, small $(0.2-3 \mu \mathrm{m})$ and fairly irregular in size and shape. This type of structure is similar to the surface aggregate described above (Fig. $\underline{9}$, bottom). Figure $10 \mathrm{c}$ shows a higher degree of organization of the fibrillar material, in the form of "wall pieces, " than in previous photographs. Based on qualitative ionic microprobe analysis, oxygen and carbon were common in wall edges of the organic matter; chlorine, sodium, sulphur, and magnesium were also major elements issued from seawater. Some analyses also indicated silicon. Diversity of cloud components is also apparent: a small (maximum size $13.5 \mu \mathrm{m}$ ) quartz grain coated with organic matter was noted (Fig. 10d) with a bulk elementary composition of oxygen, carbon, silicon, chlorine, and sodium; diatoms were entrapped in the polysaccharidic network of the cloud (Fig. 10e); a mineral aggregate, supposedly clayey (Fig. 10f) as suggested by the microprobe analysis: oxygen and carbon from organic matter, chlorine, sodium, sulphur, magnesium associated with oxygen and carbon is from seawater; silicon, aluminium, magnesium, iron, potassium belong to clays; non identified, rounded, most probably biogenic bodies (Fig. $10 \mathrm{~g}, \mathrm{~h}$ ) are associated with the organic network of the cloud. 

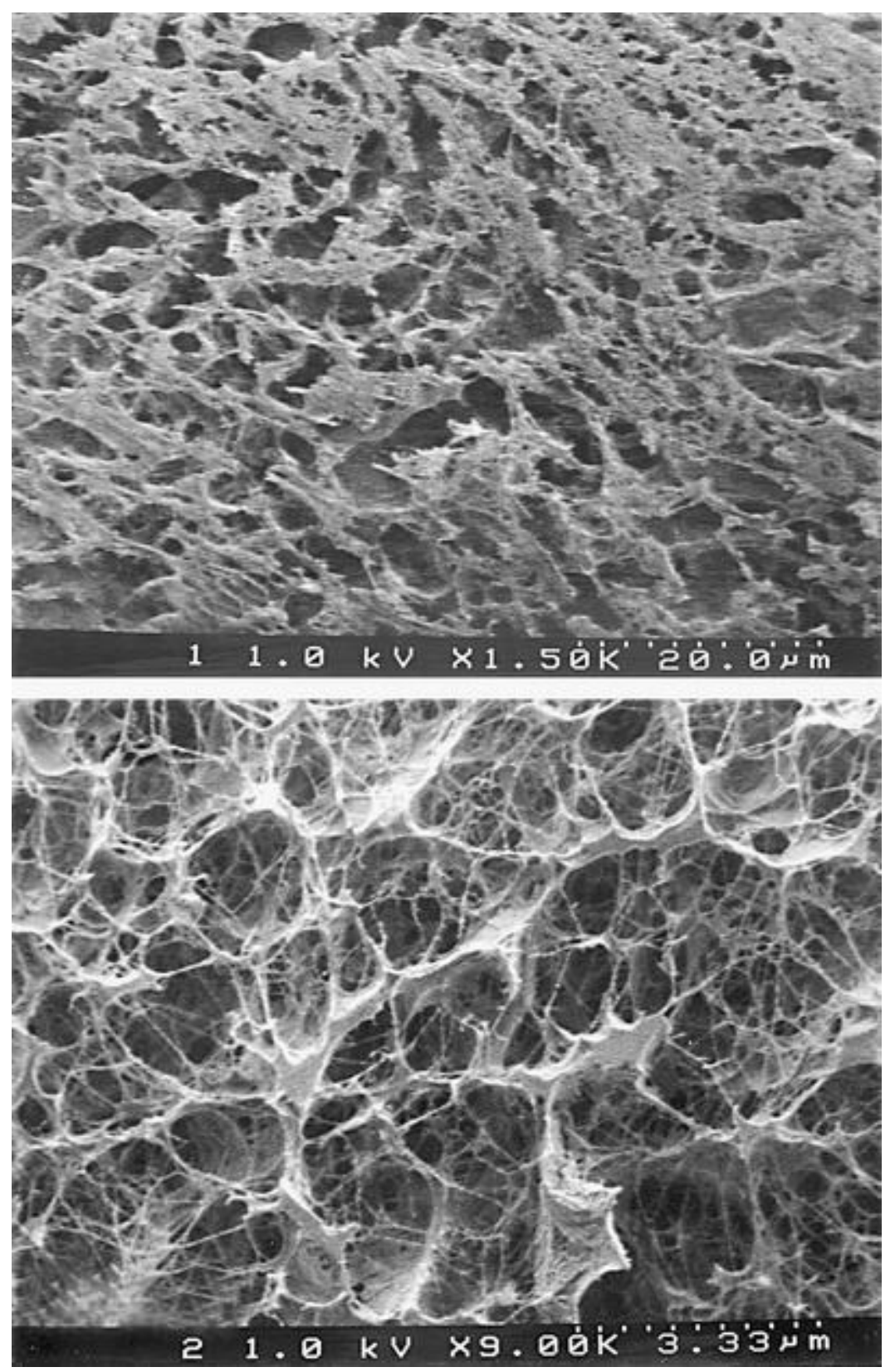

Fig. 9 Cryo-SEM of surface macroaggregates. Top Organic matter (greyish surfaces) surrounds 4- to $13-\mu \mathrm{m}$ pores $(1,500 \times)$; bottom highly porous material contains polysaccharidic threads and membranes surrounding small (ca. $1.5 \mu \mathrm{m}$ ) pores $(9,000 \times)$ 

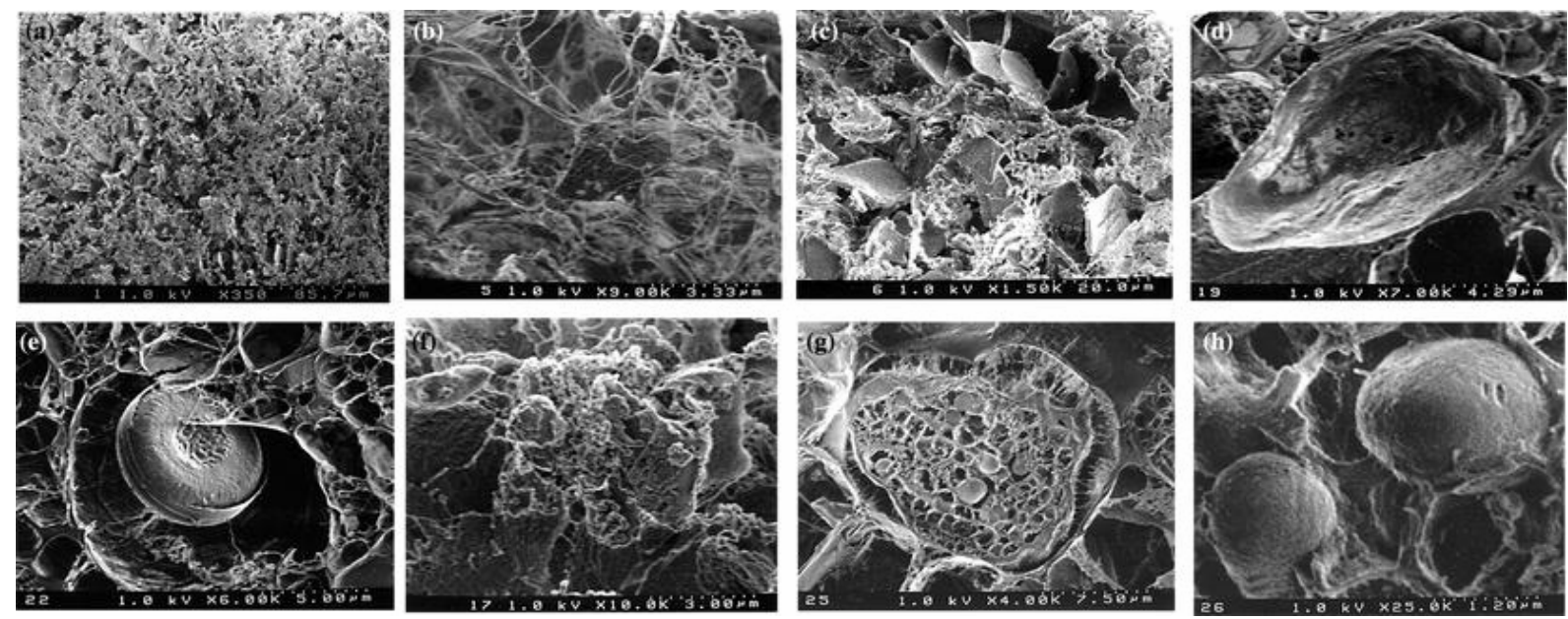

Fig. 10 Cryo-SEM of clouds. a The aggregate displays an association of pores (ca. 4-30 $\mu \mathrm{m}$ in mean dimension) and an organic network (350x). b At greater magnification $(9,000 \times)$, the same organic network appears constituted by threads and membranes of biogenic polysaccharidic units. c The presence of "wall pieces" resulting from the tightening of organic fibrils, visible in $\mathbf{b}(1,500 \times)$. d Silty quartz particle. e Diatom frustule and links between diatomaceous exopolymers and the bulk organic network. f Clayey aggregate. $\mathbf{g}$, $\mathbf{h}$ Non-identified biogenic bodies

\section{Discussion and conclusions}

Regardless of sampling location and depth, both types of macroaggregates-surface and clouds-displayed a very similar species composition. The similarity between the two types was also evident with regard to the chemical composition of these samples (unpublished data) that confirmed the common composition of the macroaggregates (Kovac et al. 2002). The predominant phytoplankton group was that of diatoms as reported in previous northern Adriatic mucous events and marine snow (Fanuko and Turk 1990; Stachowitsch et al. 1990; Revelante and Gilmartin 1991; Herndl 1992; Degobbis et al. 1995; Mingazzini and Thake 1995; Myklestad 1995; Baldi et al. 1997; Najdek et al. 2002). Other groups were present as well, such as dinoflagellates, microflagellates, and coccolithophorids in both surface aggregates and clouds.

The predominance of diatoms in the 2000 event is also supported by the quantitative analyses of the interstitial water, that drawn off the gelatinous matrix, and of the aggregate-free surrounding seawater sampled at the same time (Table $\underline{1}$ ). In both samples diatoms represented $>50 \%$ of the total cell numbers, although phytoplankton cells from the surrounding water can contributed partly to the total counts in the interstitial water due to the sampling procedure. The most abundant diatoms in the latter sample were Cyclotella sp., Cylindrotheca closterium, and Pseudo-nitzschia pseudodelicatissima. In contrast, a different species composition was observed in the surrounding seawater with Chaetoceros $\mathrm{sp}$. being the predominant diatom and with a much lower total abundance (approximately 6 times). This was the case not only during this mucous event but also during previous events. Different taxonomic composition could be due to independent biological processes occurring in the aggregates (preferential growth of some diatom species, reduced grazing pressure, interactions between phytoplankton and bacteria) with respect to the water column (Degobbis et al. 1995, 1999; Najdek et al. 2002). 
Although both types of macroaggregates had similar phytoplankton groups, there were differences concerning dominant species and life stages (degradation). The predominant live species in the clouds was Cylindrotheca closterium, while in the surface macroaggregates other diatoms (Cyclotella sp. and Pseudo-nitzschia pseudodelicatissima) were also abundant. Dinoflagellate diversity was lower in the clouds and only a few specimens were alive, whereas in the surface aggregates live specimens of Heterocapsa sp. and Prorocentrum spp. were quite abundant. Several authors (Degobbis et al. 1995; Baldi et al. 1997; Najdek et al. 2002) reported similar results in different-aged aggregates of the northern Adriatic. In 1991 and 1997 events, persisting for more than 2 months, June-July, macroaggregates were colonized by $P$. pseudodelicatissima, Cyclotella sp., Nitzschia tenuirostris, Prorocentrum balticum, and P. minimum (Degobbis et al. 1995) or other pelagic diatoms (Najdek et al. 2002). Older aggregates (August-September) were predominantly enriched with C. closterium (Degobbis et al. 1995; Najdek et al. 2002). In the present samples, this shift occurred within 1 month. Laboratory experiments on the northern-Adriatic strain of $C$. closterium have shown significant reproduction of the species in a filamentous gelatinous matrix (Monti et al. 1995), which could also explain its intense growth in natural macroaggregates. It is likely that $C$. closterium has a better capability to reproduce in mucous than other species and thus prevails over them (Degobbis et al. 1999).

The fact that $C$. closterium was the dominant live species in the clouds while other diatoms were already dead or senescent suggests that the clouds represented a more mature stage in organization as well as in physical transformation. The highly degraded nature of the clouds was furthermore confirmed by pigment analyses (Malej et al. 2001) where the highest chlorophyllide a levels, the most important chlorophyll a breakdown product in senescent phytoplankton (Jeffrey 1974), were present.

In addition to light microscopy analyses, both types of aggregates were inspected also at the fine structural level. The cryo-SEM technique revealed the fibrillar structure of the organic matrix. Such structure has been reported for colloids (Leppard et al. 1997; Santschi et al. 1998; Wilkinson et al. 1999), marine snow (Alldredge and Silver 1988; Alldredge et al. 1993; Passow et al. 1994; Mopper et al. 1995; Leppard et al. 1996), and macroaggregates (Giani 2002) and is also similar to that of microbially derived organic matter in soils (Chenu and Jaunet 1992; Malam Issa et al. 1999), sediments (Défarge et al. 1996), and humic flocs (Croué et al. unpublished data). The structure of such organic networks results from the autoorganization of microbial polysaccharidic exopolymers. The geometric organization reflects the pattern of forces applying to polysaccharidic-glycoproteic fibers, seawater cations, and water itself. These forces are, firstly, hydration forces controlled by hydrophilic and hydrophobic sites in the glucidic macromolecules, secondly, strong forces developed along low-angle contacts between fibers, in particular within bunches of fibrils, and thirdly, cationically bonded forces between fibers or bunches of fibrils. The regular, curvilinear forms of the surfaces within the network are similar to so many forms in nature and correspond to fractal-type geometries from the mathematical point of view and to the lower-energy status of the surface forces within the bulk material from a physical point of view (Hildebrandt and Tromba 1986). 
An interesting relation can be drawn, from this point of view, between the rigidity of the clouds and the development of the organic frame. The organization of the organic material within the clouds resulted in the formation of "wall pieces" ("re-inforced walls ${ }^{\prime \prime}$ ) delineating pores, approximately 6-15 $\mu \mathrm{m}$ in mean dimension. Such walls are well visible in Fig. 10 c and correspond to most of the pores visible in Fig. 10a. In

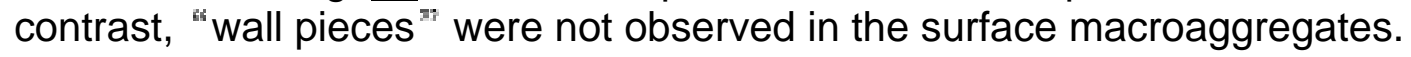

In the rearranged organic matrix of the clouds, a variety of particles other than phytoplanktonic were observed (Figs. $\underline{6}, 10 \mathrm{~d}-\mathrm{h}$ ). Besides the dominant polysaccharidic-glycoproteic organic matter of the aggregates, an abundant nonliving component was present in the form of broken cell remains, crustacean cuticles, detritus, and mineral particles. The latter could originate from suspended sediment, phytoplankton skeletal parts (diatom silica frustules and calcite coccoliths), and atmospheric inputs of allochtonic material. The silty grain observed in Fig. 10d may well have been transported by wind. The intense scavenging capacity of mucous, to incorporate all suspended particles, is reflected by the significantly lower concentration of suspended matter in the aggregate-free seawater (Malej et al. 2001). The results suggest that organic and inorganic particles contribute to a higher rigidity of macroaggregates, although the rigidification of the pore walls in the clouds is "self-processed" and results from a progressive increase, with time, of the fibrils association and organization. Physical conditions of the surrounding media also have an important role in the formation of aggregates (Ransom et al. 1998). Zutic and Svetlicic (2000) reported that the shape and size of northern Adriatic macroaggregates are influenced by local hydrodynamics (turbulence and shear) and the proximity of sea surface and density interfaces in the water column.

Elemental microprobe analysis did not reveal any significant difference in samples collected for previous studies on the northern Adriatic aggregates (Pettine et al. 1995; Penna et al. 2000; Mecozzi et al. 2001; Kovač et al. 2002). Besides organic matter ( $\mathrm{C}$ and $\mathrm{O}$ ) and seawater ions $(\mathrm{Cl}, \mathrm{Na}, \mathrm{S}, \mathrm{Mg}, \mathrm{Ca})$, other elements (Al, $\mathrm{Mg}, \mathrm{Fe}$, $\mathrm{K}, \mathrm{Si})$ most probably reflect the presence of clays. The presence of Si can also be attributed to abundant diatoms within aggregates. Recent studies indicate the importance of intracellular silica pools, which, like silicified frustules, can enrich the organic matrix at the time of cell lysis and decomposition (Martin-Jézéquel et al. 2000; Bertermann et al. 2003).

Until now, image analyses (light microscopy, transmission electron microscopy) of organic material were obtained on marine snow particles and colloids. The combination of light microscopy and cryo-SEM techniques permitted the inspection of species/particle composition and particle-organic matrix associations of copious mucous aggregates. Information on species composition and degradation of phytoplankton was completed with cryo-SEM analysis. This device is an indispensable tool for determining in situ organic texture in natural aggregates by preserving fragile and highly hydrated organic netted structures. The results confirm previous findings on marine snow, that polysaccharide fibrils constitute the structural framework of the mucous matrix. However, the organization of the fibrillar framework in samples of mucous aggregates proved to be different in two types of samples collected in June 2000, respectively at 12-15 m depth (clouds) and at the water surface. Water-column clouds showed a more condensed structure, resulting from the tighter association of the fibrils within "pore walls." Surface macroaggregates 
were, in contrast, less dense and more irregularly organized. Macroaggregates had, on average, a very heterogeneous particle composition, with diatoms the dominant biotic component. Inorganic particles in the form of plankton remains and minerals could lead to lower porosity and greater rigidity of clouds. The physiological stage of phytoplankton cells (mostly senescent and degraded or empty skeletal parts) and the predominance of one live species, Cylindrotheca closterium, suggest a more mature stage of clouds, from the auto-organization point of view. However, originally the same organic matrix organized in these two types undergoes similar time-dependant degradation processes (i.e., microbial and photochemical). In addition, physical conditions of the surrounding environment (pycnocline layer vs air-water interface) are likely to be important for the aggregation and transformation of aggregates. To elucidate the growing questions about time evolution of macroaggregates, future studies should include dye marking and tracking of mucilage material.

Acknowledgements These results are based in part on joint research supported by the Ministry of Education, Science and Sport, Ministry of Environment, Spatial Planning and Energy, Ministry of Agriculture, Forestry and Food, and Ministry of Defence of the Republic of Slovenia (grant no. V1-0360-00). The authors appreciate the help of Annie Richard (University of Orléans) for technical assistance in cryoSEM observations.

\section{References}

Alldredge AL, Silver MW (1988) Characteristics, dynamics and significance of marine snow. Prog Oceanogr 20:41-82

Alldredge AL, Passow U, Logan BE (1993) The abundance and significance of a class of large, transparent organic particles in the ocean. Deep-Sea Res I 40:11311140

Arnarson TS, Keil RG (2000) Mechanisms of pore water organic matter adsorption to montmorillonite. Mar Chem 71:309-320

Baldi F, Minacci A, Saliot A, Mejanelle L, Mozetið P, Turk V, Malej A (1997) Cell lysis and release of particulate polysaccharides in extensive marine mucilage assessed by lipid biomarkers and molecular probes. Mar Ecol Prog Ser 153:45-57

Bertermann R, Kröger N, Tacke R (2003) Solid-state ${ }^{29}$ Si MAS NMR studies of diatoms: structural characterisation of biosilica deposits. Anal Bioanal Chem 375:630-634

Chenu C, Jaunet A-M (1992) Cryoscanning electron microscopy of microbial extracellular polysaccharides and their association with minerals. Scanning 14:360364

Cowen JP, Holloway CF (1996) Structural and chemical analysis of marine aggregates: in situ macrophotography and laser confocal and electron microscopy. Mar Biol 126:163-174 
Decho AW (1990) Microbial exopolymer secretions in ocean environments: their role(s) in food webs and marine processes. Oceanogr Mar Biol Annu Rev 28:73-153

Défarge C (1997) Apports du cryo-microscope électronique à balayage et du microscope électronique à balayage haute résolution à l'étude des matières organiques et des relations organo-minérales naturelles. Exemple des sédiments microbiens actuels. CR Acad Sci Paris 324:553-561

Défarge C, Trichet J, Jaunet A-M, Robert M, Tribble J, Sansone FJ (1996) Texture of microbial sediments revealed by cryo-scanning electron microscopy. J Sediment Res 66:935-947

Degobbis D, Fonda Umani S, Franco P, Malej A, Precali R, Smodlaka N (1995) Changes in the northern Adriatic ecosystem and the hypertrophic appearance of gelatinous aggregates. Sci Total Environ 165:43-58

Degobbis D, Malej A, Fonda Umani S (1999) The mucilage phenomenon in the northern Adriatic Sea. A critical review of the present scientific hypotheses. Ann Ist Super Sanità 35:373-381

Faganeli J (1989) Sedimentation of particulate nitrogen and amino acids in shallow coastal waters (Gulf of Trieste, northern Adriatic). Mar Chem 26:67-80

Faganeli J, Kova č N, Loskov̌ek H, Pezdið J (1995) Sources and flux of particulate organic matter in shallow coastal waters characterized by summer macroaggregate formation. Biochemistry 29:71-88

Fanuko N, Turk V (1990) The oceanologic properties of the seawater in the Gulf of Trieste before and during the "mare sporco" phenomenon (summer 1988). Boll Oceanol Teor Appl 8:3-11

Fanuko N, Rode J, Draslar K (1989) Microflora from the Adriatic mucous aggregations. Biol Vestn 37:27-34

Fonda Umani S, Ghirardelli E, Specchi EM (1989) Gli episodi di mare sporco nell' Adriatico dal 1729 ai giorni nostri. Regione Autonoma Friuli-Venezia Giulia, Direzione regionale dell'Ambiente, Trieste

Giani M (2002) Distribuzione e variazioni temporali della sostanza organica nell ' Adriatico settentrionale. Archo Oceanogr Limnol 23:29-41

Hama J, Handa N (1992) Diel variations of water-extractable carbohydrate composition of natural phytoplankton populations in Kunu-Ura Bay. J Exp Mar Biol Ecol 62:159-176

Heissenberger A, Leppard GG, Herndl GJ (1996) Ultrastructure of marine snow II. Microbiological consideration. Mar Ecol Prog Ser 135:299-308 
Herndl GJ (1992) Marine snow in the northern Adriatic Sea: possible causes and consequences for a shallow ecosystem. Mar Microb Food Webs 6:149-172

Hildebrandt S, Tromba AJ (1986) Mathematics and optimal form. Freeman, New York

Ittekkot V, Degens ET, Brockmann V (1982) Monosaccharide composition of acidhydrolyzable carbohydrates in particulate matter during a plankton bloom. Limnol Oceanogr 27:770-776

Jeffrey SW (1974) Profiles of photosynthetic pigments in the ocean using thin-layer chromatography. Mar Biol 26:101-110

Kaiser K, Guggenberger G (2000) The role of DOM sorption to mineral surfaces in the preservation of organic matter in soils. Org Geochem 31:711-725

Kova $\mathrm{E}$, Faganeli J, šket B, Bajt O (1998) Characterization of macroaggregates and photodegradation of their water soluble fraction. Org Geochem 29:1623-1634

Kovar N, Bajt O, Faganeli J, šket B, Orel B (2002) Study of macroaggregate composition using FT-IR and ${ }^{1} \mathrm{H}-\mathrm{NMR}$ spectroscopy. Mar Chem 78:205-215

Leppard GG, Heissenberger A, Herndl GJ (1996) Ultrastructure of marine snow I. Transmission electron microscopy methodology. Mar Ecol Prog Ser 135:289-298

Leppard GG, West MM, Flannigan DT, Carson J, Lott JNA (1997) A classification scheme for marine organic colloids in the Adriatic Sea: colloid speciation by transmission electron microscopy. Can J Fish Aquat Sci 54:2334-2349

Malam Issa O, Trichet J, Défarge C, Couté A, Valentin C (1999) Morphology and microstucture of microbiotic soil crusts on a tiger bush sequence (Niger, Sahel). Catena 37:175-196

Malej A (1995) Gelatinous aggregates in the northern Adriatic Sea. Bull Inst Oceanogr 15:149-157

Malej A, Malacic V, Mozetiz P, Kovaz N, Sotlar Z, Flander Putrle V, Petelin B, G ermelj B (2001) Marine mucous and possible measures for the mitigation of consequences (in Slovene). (Report) National Institute of Biology, Piran, pp 1-82

Marchetti R, Iacomini M, Torri G, Focher B (1989) Caratterizzazione preliminare degli essudati di origine planctonica raccolti in Adriatico nell "estate 1989. Acqua Aria 8:883-887

Martin-Jézéquel V, Hildebrand M, Brzezinski M (2000) Silicon metabolism in diatoms: implications for growth. J Phycol 36:821-840

Mecozzi M, Acquistucci R, Di Noto V, Amici M, Pietrantonio E, Cardarilli D (2001) Characterization of marine mucilage samples in Tyrrhenian and Adriatic Sea: structure similarities between mucilage samples and the insoluble fraction of the 
marine humic substance. Chemosphere 44:709-720

Mingazzini M, Thake B (1995) Summary and conclusions of the workshop on marine mucilages in the Adriatic Sea and elsewhere. Sci Total Environ 165:9-14

Monti M, Welker C, Dellavalle G, Casaretto L, Fonda Umani S (1995) Mucous aggregates under natural and laboratory conditions: a review. Sci Total Environ 165:145-154

Mopper K, Zhou J, Ramana KS, Passow U, Dam HG, Drapeau DT (1995) The role of surface-active carbohydrates in the flocculation of a diatom bloom in a mesocosm.

Deep-Sea Res 42:47-73

Myklestad SM (1995) Release of extracellular products by phytoplankton with special emphasis on polysaccharides. Sci Total Environ 165:155-164

Najdek M, Degobbis D, Miokovič D, Ivanêic I (2002) Fatty acid and phytoplankton composition of different types of mucilaginous aggregates in the northern Adriatic. $J$ Plankton Res 24:429-441

Passow U, Alldredge AL, Logan BE (1994) The role of particulate carbohydrate exudates in the flocculation of diatom blooms. Deep-Sea Res 41:335-357

Penna N, Berluti S, Penna A, Ridolfi F (2000) Study and monitoring of mucilage in the Adriatic Sea. Water Sci Technol 42:299-304

Pettine M, Pagnotta R, Liberatori A (1995) Composition of mucilaginous macroaggregates and hypotheses for their formation. Ann Chim 85:431-441

Posedel N, Faganeli J (1991) Nature and sedimentation of suspended particulate matter during density stratification in shallow coastal waters (Gulf of Trieste, northern Adriatic). Mar Ecol Prog Ser 77:135-145

Ransom B, Shea KF, Burkett PJ, Bennett RH, Baerwald R (1998) Comparison of pelagic and nepheloid layer marine snow: implications for carbon cycling. Mar Geol 150:39-50

Revelante N, Gilmartin M (1991) The phytoplankton composition and population enrichment in gelatinous "macroaggregates" in the northern Adriatic during the summer of 1989. J Exp Mar Biol Ecol 146:217-233

Santschi PH, Balnois E, Wilkinson KJ, Zhang J, Buffle J, Guo L (1998) Fibrillar polysaccharides in marine macromolecular organic matter as imaged by atomic force microscopy and transmission electron microscopy. Limnol Oceanogr 43:896-908

Stachowitsch M, Fanuko N, Richter M (1990) Mucus aggregates in the Adriatic Sea: an overview of stages and occurrences. Pubbl Stn Zool Napoli I Mar Ecol 11:327350 
Stevenson FJ (1982) Humus chemistry. Wiley-Interscience, New York

Utermöhl H (1958) Zur Vervollkommung der quantitativen Phytoplankton-Methodik. Mit Int Verein Theor Angew Limnol 9:1-38

Wilkinson KJ, Balnois E, Leppard GG, Buffle J (1999) Characteristics features of the major components of freshwater colloidal organic matter revealed by transmission electron and atomic force microscopy. Colloids Surf A Physicochem Eng Aspects 155:287-310

Zutic V, Svetlicis V (2000) Interfacial processes. In: Wangersky P (ed) The handbook of environmental chemistry, vol 5, part D. Springer, Berlin Heidelberg New York, pp 149-165 